\title{
James Bond's forgotten beginnings: television adaptations
}

Book or Report Section

Accepted Version

Bignell, J. (2018) James Bond's forgotten beginnings: television adaptations. In: Strong, J. (ed.) James Bond Uncovered. Palgrave Studies in Adaptation and Visual Culture. Palgrave Macmillan, Basingstoke, pp. 41-60. ISBN 9783319761220 doi: https://doi.org/10.1007/978-3-319-761237_3 Available at http://centaur.reading.ac.uk/69143/

It is advisable to refer to the publisher's version if you intend to cite from the work. See Guidance on citing.

To link to this article DOI: http://dx.doi.org/10.1007/978-3-319-76123-7_3

Publisher: Palgrave Macmillan

All outputs in CentAUR are protected by Intellectual Property Rights law, including copyright law. Copyright and IPR is retained by the creators or other copyright holders. Terms and conditions for use of this material are defined in the End User Agreement. 


\section{www.reading.ac.uk/centaur}

\section{CentAUR}

Central Archive at the University of Reading

Reading's research outputs online 
Bignell, J. (2018) James Bond's forgotten beginnings: television adaptations. In: Strong, J. (ed.) James Bond Uncovered. Palgrave Studies in Adaptation and Visual Culture. Palgrave Macmillan, Basingstoke, pp. 41-60. ISBN 9783319761220. Doi: 10.1007/9783-319-76123-7_3.

\section{James Bond's Forgotten Beginnings: Television Adaptations}

Jonathan Bignell

This chapter addresses the remediations of Ian Fleming's James Bond character by unpacking the complex but little known story of Bond's early life in television. ${ }^{1}$ In the 1950s and 1960s versions of Bond moved across and between the media of novel, screenplay, live studio-shot television play, location-filmed television series and cinema film, and from the start Fleming sought to exploit the character on screen. There were numerous approaches made to Fleming about adapting his Bond novels for television, both for US and for British audiences. Eventually, the first screen Bond was seen in 1954 when the US television network CBS broadcast Casino Royale as a live studio-shot drama, but for decades thereafter this was a 'lost' programme. ${ }^{2}$ In 1956, Fleming wrote a TV pilot, James Gunn - Secret Agent, for a planned episodic series of television films. The series was never made, but he reworked it into the Bond novel Dr No (1958), which would become the first cinema adaptation in 1962. Before and after this period in the mid-1950s and early 1960s, there were many other abortive attempts to get Bond onto the television screen, but the broadcast medium's evanescence and more complex means of international distribution than cinema have marginalised its role in the story.

This chapter focuses on the more or less 'lost' and invisible television Bond, but the missing Bond was a structuring absence that was compensated for by the appearance 
of numerous Bond-like figures in television series that claimed no direct connection with Fleming's protagonist. Despite repeated failures to make a Bond television series, the success of the literary and film Bond was an important supporting context for the cycle of British and American television series in the early 1960s that drew on Bondian iconography and narrative tropes. ${ }^{3}$ There were many such spy adventure series, such as The Avengers (ABC for ITV 1961-9, ABC USA 1966-9), Danger Man (ITC for ITV 1960-9, aka Secret Agent CBS 1961) and The Man from U.N.C.L.E. (Arena/MGM for NBC 1964-8, BBC1 1965-6). These were, in a sense, echoes of an absent television Bond who never appeared as the protagonist of a British television drama, and only once in the USA. Tracking the relationships between Bond and television is the story of a long series of failures to gain legal rights for a television Bond, and displacements from television to literary or film representations of the character. This chapter is in part an historiographic account of Bond's presence and absence on television, but its underlying conceptual argument is that there were repeated metonymic displacements of Bond and the fictional world created around him. A whole panoply of television spies, adventurers and investigators repeated and disseminated fictions that echoed Fleming's creation, many of them British-made, in a cycle of television action adventure series that proliferated in the 1960s (Chapman 2002).

The early history of Bond adaptations is one of connections made and broken, and of transnational networks forged and disrupted by Fleming himself and by his many contacts. Movement between media is one kind of transition that this chapter addresses, but the role of international television trading and offshore production is another. British and American television had different and incompatible technologies of electronic 
television broadcasting; British viewers watched television sets whose electronic pictures were made using the PAL format, while American television transmission was in the NTSC format. So live television, and later videotape productions, had to be put onto celluloid film for television screening if programmes were exported across the Atlantic. Cinema film was already an international technology, and the need to make television on film to move it easily from one country to another brought the industries of cinema and television production together. Locating the first Bond film in Jamaica, and trying to make a filmed television Bond there, as explained below, mediated geographically between the territories and spheres of influence of Britain and the USA, for example, connecting them together. The representation of places that signify international modernity, like the airports, hotels and resorts that feature from the television Casino Royale onwards, and the ability to travel easily between places that marks Bond's (and his antagonists') power to control the fictional world, correspond with the fact that the Bond novels, films and putative television programmes were commodities that were traded internationally. Bond fictions forge business links, and depend on them. The story of how Bond adaptations came to be made, or failed to be made, illuminates questions of medium specificity and hybridity, the shifting boundaries of genre, issues of property and copyright, and the significance of specific places, technologies and commercial contexts.

\section{Bond on TV: Casino Royale}

From before the publication of Fleming's first Bond novel, film adaptations were repeatedly mooted and then abandoned. Fleming's fellow author and journalist colleague at the Sunday Times, Paul Gallico, recommended Casino Royale (1953) to his own 
Hollywood agent Swanee Swanson at manuscript stage, as a prospect for film adaptation (Lycett, 1996: 232-3). Fleming was aware of the financial potential of selling subsidiary rights in his work, and ways of maximising his income from his writing. He bought a small theatrical agency business, Glidrose Ltd., in 1952 on the advice of his accountant Vallance Lodge, so that he could reduce his liability for tax payable on his personal income by selling his authorial rights over others' uses of his work to Glidrose. ${ }^{4}$ However, Fleming retained control of the rights to serializations, broadcasts and films, and he took Gallico's advice to gain access to Swanson's expert knowledge. When he was negotiating the contract with Jonathan Cape for the publication of Casino Royale, he took an interest in each clause relating to the adaptation of his work, commenting on the fees he wanted to receive if he sold rights to serialise it (in magazines and newspapers, for example), payment for film rights, and the separate clause relating to rights for television and radio broadcasting. ${ }^{5}$ Fleming was personally involved in the business of screen adaptation of his work, which would go on to have both advantages and disadvantages.

Despite Fleming's exploratory contact with Swanson in the USA, the first to show interest was a UK film production company, Associated British Pictures Corporation (ABPC). But the company thought Casino Royale was not a substantial enough story for a film, and wanted rights to Fleming's second novel as well (Live and Let Die, 1954) so that they could synthesise the two into a single film. ABPC's interest was not solely in making films for cinema release, but also using Elstree Studios, which it owned, as a base for shooting filmed television programmes. In 1957, APBC filmed a television coproduction at Elstree, The New Adventures of Martin Kane (Towers of London/Ziv for 
NBC 1957, aka Martin Kane, Private Investigator for ITV 1958-9). Making an action film out of a synthesis of Fleming's Bond novels was a logical development of the company's activities. ABPC had business links with the British ABC Television company, which held the weekend franchise for the Midlands and North regions of the commercial ITV television network in the UK. Commercial television broadcasting was linked economically with production companies who made relatively low-budget cinema films and also filmed television fiction using the same facilities and production personnel. Elstree's soundstages were used in the late 1950s and early 1960s by ABC, ABPC and other companies for filmed television police drama, historical series and the adventure series International Detective (Official/APBC for ITV 1959, syndicated in the USA 1959), for example. The production medium of film linked the television and cinema industries and was the medium used for international import and export of both cinema and popular television fiction (Bignell 2010). American film producers invested in cinema and filmed television projects made in Britain, known as 'runaway' productions, financed by American money but made in overseas studios at comparatively low cost. The mooted Bond films and television series of the late 1950s would have been this kind of product.

The US film and entertainment company Music Corporation of America (MCA) also enquired about film rights, but neither MCA nor APBC persisted in the negotiations. In January 1953, however, the film producer Sir Alexander Korda wrote to Fleming to say that he had read a proof copy of Live and Let Die, and found it compelling and exciting (F. Fleming 2015, 53-5). Korda was interested in an original film script from Fleming, rather than an adaptation, but he showed the manuscript of Live and Let Die to 
the film directors Carol Reed and David Lean. Nothing came of this, but in May 1954, the Russian-born American producer and director Gregory Ratoff paid $\$ 600$ for a sixmonth option on the film rights to Casino Royale. An option is a time-limited opportunity for a producer to put a film or television programme into production, by making further deals to raise finance, engage screenwriters and perhaps key performers, and attempt to interest distributors in the finished product, for example. If the production does not get started, the option will lapse and once again becomes available for sale to someone else. In March 1955, Ratoff paid \$6,000 to convert his option on the film rights of Casino Royale into exclusive rights in perpetuity. Ratoff died in 1960 and his widow sold the rights to Charles K. Feldman, who produced the 1967 adaptation featuring David Niven. Meanwhile, Fleming's American agent Curtis Brown negotiated a deal with the US television network CBS to pay $\$ 1,000$ for an option on the live television rights to Casino Royale. Live television rights are a form of performance rights, and separate from cinematographic rights which apply to a pre-recorded adaptation such as a cinema film or filmed television programme. It was therefore possible for Curtis Brown to make the television deal with CBS without a direct impact on possible sales of the film rights to the novel. The main production method for television fiction in Britain and the USA in the 1950s was to shoot a continuous performance live in a multi-camera television studio, in black-and-white, using electronic cameras. The output of the three or four cameras on set was mixed live in the studio gallery and broadcast by a national transmitter network. Brief, previously-shot filmed sequences could be played-into the live broadcast while it was being made, for example to show special effects (like explosions) that could not be realized safely or effectively in the studio. Videotape for making recorded programmes 
became available from 1956 but was used for lower-budget drama (like soap opera) in the USA, though it was more widely adopted in Britain. ${ }^{6}$ Film was also used to make whole television programmes, and this is discussed further below, in relation to the project that became $\operatorname{Dr}$ No, but the Casino Royale of 1954 was always intended as a live broadcast. It was this one-hour television adaptation, screened at $8.30 \mathrm{pm}$ on 21 October 1954 in the series Climax! Mystery Theatre (CBS 1954-8) sponsored by the Chrysler Corporation, that first put Bond on screen.

The Climax! series was a drama anthology, meaning that each episode was a new and different story, with different characters and setting every time, but each was screened under the same overall title and the episodes were planned as a single season. ${ }^{7}$ The programme was bracketed by the sponsor's advertising, comprising played-in film of Chrysler's current cars, and the opening titles for the story itself were a stock sequence used each week on Climax!, thus providing a consistent and unifying introduction. This introduction comprised a shot of a brief forward movement towards the three turret lenses on the front of a TV studio camera, ${ }^{8}$ and emphatic narration telling the viewer that this programme is 'Live, from Television City in Hollywood!' This is followed by a spoken welcome delivered by the series host, actor William Lundigan, who sat perched on a study desk holding a baccarat shoe. The host's direct address to camera, delivering a premonitory comment about the risk inherent in gambling, and telling the viewer that the programme is 'based on the bestseller by Ian Fleming', both establishes an entry into a fictional Bond world of high-stakes risk-taking in elegant settings, but also frames the drama with a paternalistic tone that is a long way from the violent and corrupt world we are about to enter. An opening shot, captioned 'Act I', of a set representing a casino 
exterior, shows the doors of a casino, with customers greeted by a doorman. Approaching the doors, Bond (Barry Nelson) is shot at with a revolver held by an unseen assassin positioned almost next to the camera. Spatially, the drama opens out from Lundigan's study to the exterior of the casino, and as Bond goes inside the camera moves into its large lobby and gaming room. Extras in evening dress and staff in black tie formal wear give an impression of busyness in this public space. Among the adaptation's significant differences from the novel is that Bond is now an American who is called Jimmy Bond by the other characters, and his associate Clarence (not Felix) Leiter (Michael Bate) is from the British Secret Service. Camera movement following Bond into the space closes up on Bond and Leiter, framing them more tightly to suggest an intimate exchange. The almost continuous orchestral music, which repeatedly peaks in dramatic stings amid a texture of unresolved symphonic structures led by the strings, is very reminiscent of Hollywood film noir and other gangster and thriller cinema. ${ }^{9}$

Leiter and Bond's conversation comprises exposition in which Bond explains baccarat to Leiter, while Leiter covertly reveals that Le Chiffre is Bond's target for humiliation by defeat in a high-stakes game. The character of Valerie Mathis (Linda Christian) combines Fleming's love interest for Bond, Vesper Lynd in the novel, with French agent René Mathis who is Bond's main associate in the published version. In keeping with the continuous performance of live studio drama, characters' movements are choreographed to avoid the need for cuts between cameras. As Bond and Valerie stroll past the camera arm-in-arm, Le Chiffre (Peter Lorre) and three henchmen sweep in and towards it. Le Chiffre's henchmen threaten Leiter, and Bond is threatened with his former lover Valerie's death if he wins at cards. The casino setting, costumes and music 
are each similar to those of the film Casablanca (Michael Curtiz 1942), for example, based on a play and confined largely to interior casino settings, and the noir world of hard-boiled detectives in a version of Raymond Chandler's novel The Long Goodbye (1953) had provided the source for the first Climax! episode earlier that month. To a 1954 audience, Casino Royale would have looked quite similar to other dramas in Climax! and the other anthologies of live, adapted and original dramas of the period like The US Steel Hour (ABC 1953-5, CBS 1955-63) or Kraft Television Theatre (NBC 1947-58).

Although the 1954 Casino Royale might now seem very inept in realisation, the average budget of no more than $\$ 40,000$ (Hawes 2002: 178) and the problems of making live drama need to be borne in mind. Climax! was among the top ten ratings winners in the mid-1950s, regularly reaching about 10 million homes.

The first commercial break is followed by the baccarat sequence, captioned 'Act II', which is shot in a complex alternation of overhead shots of the cards and shot-reverse shots between the card-players. At a slower pace and with fewer problems of timing and choreography to consider, Nelson and Lorre are able to give greater depth and complexity to their performances, using eye movements, facial expression and gesture much more subtly than in the long shots and long takes that dominate the majority of the drama. Winning the baccarat game, Bond goes to his hotel to find Valerie, who arrives in the thrall of Le Chiffre and his henchmen who are looking for Bond's winnings. Le Chiffre tortures Bond by crushing his toes with pliers (rather than beating his testicles as in the novel), providing Lorre with an opportunity for the camera to show an extended sequence of Le Chiffre's controlled, menacing domination of Bond, who is tied up in his own bathroom. Bond escapes, and despite Valerie's entreaties Bond holds off from shooting 
Le Chiffre until he has to in order to release Valerie, who is threatened by Le Chiffre holding a razor blade to her throat in close up. The drama ends quickly, as Valerie hugs Bond, and the camera cuts back immediately to Lundigan's study. His closing remarks include an acknowledgement of the good work being done at a National Safety Congress being held that week in Chicago. He encourages the audience to take care, then the credits roll over a still shot of cards on the baccarat table. The liveness of the drama is signalled again here, by the simultaneity of this performance and the accident prevention conference. Moreover, the odd linkage of Casino Royale with accident prevention emphasises the tonal shift from the sadism of the story's final scene to this institutional and conventionalised closing motif of the homily in Lundigan's study.

Spatially and stylistically, the 1954 adaptation is very constrained, being shot entirely in a television studio. The whole drama takes place in interiors, and it is quite difficult to differentiate between the casino and Bond's hotel as different places in the story. Pace is generated in part by the drama's rapid shifts between these fictional locations, and in production they would have been adjoining sets within the one large soundstage where the drama was shot. Careful planning would have been required to ensure that the actors could get from one set to another, and cameras redeployed ready for the next scene, while action was being shot in another part of the studio. Apart from the two commercial breaks that interrupted the drama between the Acts, there could be no pauses in the performance and it would have required intense concentration and coordination between actors and crew on the studio floor, and in the director's gallery above. Apart from some brief fisticuffs, there is nothing of the physical action that might 
be expected from Bond, and there are of course no car chases and spectacular set pieces such as are now associated with Bond on screen.

Fortunately, the live programme was kinescope recorded onto three reels of $16 \mathrm{~mm}$ film while it was broadcast, ${ }^{10}$ but the film recording was then lost until its accidental discovery in 1981. One of the reasons for the neglect of the first screen Bond is probably that Climax! was among the last live drama series in prime time in the USA, as the networks moved during the 1950s from showing live drama, shot in the studio, to showing filmed television fiction that could be well-rehearsed and shot out of story sequence (Kepley and Boddy, 1980). Retakes became possible, effects sequences could be prepared in advance and more smoothly incorporated, scenes could be shot on location, and the actors and camera operators no longer had to rush from one set to another to get ready for the next live scene. Although a film record of the Casino Royale of 1954 was made, this was not so that it could be shown again. Contractual rights for the live drama would not have permitted this, and the probable intended purpose of the film record was staff training or storage in corporate records.

\section{The television origins of $\mathrm{Dr} N o$}

In November 1954 Fleming visited Swanee Swanson in California, a few weeks too late to see Casino Royale on television, and was told that Stanley Meyer who produced the US TV series Dragnet (Mark VII for NBC 1951-9) and its eponymous 1954 cinema spinoff was interested in adaptations of Live and Let Die and the forthcoming novel Moonraker (1955) (Lycett 1996: 265). But the parties could not agree the fee, and negotiations broke down. In November 1955, Swanson, via Fleming's American 
publisher Curtis Brown, was negotiating with the actor John Payne over the film rights to Moonraker. ${ }^{11}$ Meanwhile, Fleming's British publisher Jonathan Cape was also negotiating with the Rank organisation for the film rights. The British and American deals for Moonraker were mutually exclusive, because cinematic rights are normally worldwide, by contrast to television rights, and led to lengthy legal wrangling. Payne withdrew from the negotiations, and although Fleming wrote a full screenplay the Rank film also lapsed (Lycett 1996: 276).

Dr No was the first Bond film, but its genesis was as a pilot for a television series (Lyons 2009). On his frequent visits to Jamaica, Fleming had got to know Lady Jeanne Campbell, granddaughter of the newspaper magnate Lord Beaverbrook. She was based in New York, and put Fleming in contact with Henry Morgenthau III, son of the former US Treasury Secretary and associate of her grandfather. Morgenthau was a film producer, and planned to develop Jamaica as a base for television production, in particular filmed television series for the American networks. He wanted a strong property such as a Bond project to initiate the business, and Fleming therefore created the character Commander Jamaica, quickly renamed Commander James Gunn, an American secret agent closely based on Bond (Lycett 1996: 296-8). He wrote a sample treatment for a half-hour television episode in which James Gunn battles an international freelance spy of mixed Chinese and German ancestry, named Doctor No. The story was to be based in Jamaica, and would feature ballistic missiles and Doctor No's beautiful accomplice Pearl, a champion underwater swimmer. Fleming suggested his own Jamaican estate, Goldeneye, as a location, and his favourite calypso as the signature tune. He wrote a pilot script for this putative series, to be called James Gunn - Secret Agent, but by December 1955 
Morgenthau gave up on the project, having failed to interest the American studios. The ideas from this failed project became Fleming's 1958 novel $\mathrm{Dr} N o$, which was an adaptation of the draft television treatments.

In 1958, the Curtis Brown agency was in discussion with the producer David O. Selznick for exclusive film rights to Fleming's work apart from Casino Royale and Moonraker (whose rights were already assigned), but once again a Bond adaptation was abandoned. Fleming himself was in negotiation with Hubbell Robinson, head of programmes for CBS, who had approached him about writing a James Bond television series (Lycett 1996: 335-8). Fleming offered Robinson the Commander James Gunn idea that he had developed for Henry Morgenthau III. However, separately from Robinson's approaches, the head of the CBS television network William Paley had come up with an idea to make a film about casinos and Fleming was to be the screenwriter because of his acknowledged expertise about gambling. Fleming worked on the James Bond series suggested by Robinson, writing outlines for 13 episodes, one of which took place in a Monte Carlo casino. Nevertheless, the programmes were never made because of conflicts of interest between Robinson and his superior executive at CBS, Paley. The only tangible results of the CBS negotiations were an omnibus publication of the Casino Royale, Moonraker and From Russia, with Love novels which had been commissioned as a tie-in to the proposed CBS Bond series, and two short stories subsequently published in For Your Eyes Only (1960) that were based on television episode plots. These two stories, 'For Your Eyes Only' and 'From a View to a Kill', were adaptations of the television treatments Fleming wrote for Robinson and were also adapted subsequently into comic strips in the Daily Express newspaper in 1961. Much later, these titles were adopted for 
the eponymous 1981 and 1985 cinema films in the Bond franchise run by Eon Productions.

A similar story of adaptation and repurposing to that of $\mathrm{Dr}$ No occurred in the case of the novel Thunderball (1961), which was originally conceived as film script, being adapted as the 1965 film long afterwards (Lycett 1996: 354-5, 364-8). In the summer of 1958, Fleming's friend the US millionaire Ivar Bryce had just financed the film The Boy and the Bridge (1959), directed by Kevin McClory. McClory came to prominence after arranging the 140 locations $^{12}$ in 13 countries that were used in the 1957 film Around the World in 80 Days (Michael Anderson 1957), for which Kenneth Adam was art director. McClory proposed that Fleming should write an original James Bond screenplay for a film to be financed by Bryce. The film was to be made in a studio that the collaborators would establish in the Bahamas so that films made there would benefit from the Eady Levy subsidies for films made in the UK or in British territories. Bryce's lawyer Ernest Cuneo not only suggested that the James Bond project should follow the example of Around the World in 80 Days by using many exotic foreign locations, but he also pointed out that if the production company were based in the Bahamas its exports to the United States would be exempt from US taxes. Fleming wrote an extensive treatment, introducing the characters of the villain Largo, the heroine Domino, and suggested casting an unknown actor as Bond. The professional screenwriter Jack Whittingham was engaged to work on the drafts, and subsequently there were extensive legal disputes because McClory, Cuneo, Whittingham and Fleming each claimed to have contributed significant elements to what would become the novel Thunderball. 
In 1959 there were further fruitless enquiries about the television rights for James Bond. Maurice Winnick, a producer associated with the American studio MGM, was interested in developing a TV series and Fleming once again offered the outlines he had drafted for Henry Morgenthau III (Lycett 1996: 351). MGM's forays into adaptations of spy drama for the screen included the television spin-off from Carol Reed's 1949 film The Third Man (BBC/British Lion/National Telefilm Associates for BBC 1959-64, syndicated in the USA 1960), which was made partly at Elstree Studios in Britain with some sequences shot in Los Angeles. It was one of the few examples of a transatlantic co-production with the $\mathrm{BBC}$ at this time. It was much more common for independent production companies fronted by wealthy impresarios to buy rights to potential prospects for adaptation, and to try to sell the projects to major film studios or television networks, as this chapter has already shown. The most successful of these was former theatrical agent Lew Grade, whose production company ITC made programmes for the British ITV commercial television network, but also for sale to the US networks (Bignell 2005). ITC's costume adventure series The Adventures of Robin Hood (Sapphire/ITC for ITV 1955-9, CBS 1955-8) was sold to the CBS network and was followed by sales of The Buccaneers (Sapphire/ITC for ITV 1956-7, CBS 1956-7), The Invisible Man (Official/ITP for ITV 1958-9, CBS 1958-60) and Danger Man to CBS in 1961 (titled Secret Agent). Increasingly, ITC focused on globetrotting crime-fighters and spies as the basis for their productions, paralleling the cycle of Bond films in the cinema in the 1960s. Winnick's project for an MGM Bond on television failed, but one of Fleming's ideas for the James Gunn television series would at last result in the first Bond film. Fleming's solicitor, Brian Lewis, knew the London-based Canadian film producer Harry 
Saltzman, and introduced him to Fleming (Lycett 1996: 387). The result was that in 1961 Saltzman acquired an option to make films based on the James Bond character. Saltzman's production company, Woodfall Films, was a collaboration with the film director Tony Richardson and playwright John Osborne, and had made the film adaptations Look Back in Anger (Tony Richardson, 1959) from Osborne's controversial and celebrated theatre play of 1956, and Saturday Night and Sunday Morning (Karel Reisz, 1960) from the novel by Alan Sillitoe (1958). Each of these productions was part of the brief apotheosis of British cinema at the start of the 1960s, associated with a 'kitchen sink' style of realism centred on the struggles of male central characters to break free of constraining social conventions associated with women and domesticity (Hill 1986). Woodfall Films had successfully secured options to adapt source properties for films that seemed to catch the mood of the moment, just as Bond would do.

In his efforts to find financial backing for the proposed Bond film, Saltzman was assisted by the screenwriter Wolf Mankowitz who suggested that Saltzman team up with the former Hollywood agent Albert ‘Cubby’ Broccoli. Broccoli was at this time based in London and running Warwick Pictures, which had made The Red Beret (Terence Young, 1953, titled Paratrooper in the USA) and Cockleshell Heroes (José Ferrer, 1955) with director Terence Young (replaced as director of the latter film during production) and art director Kenneth Adam, each of whom would work on $\mathrm{Dr}$ No. Broccoli and Saltzman set up Eon Productions to sell the Bond idea to a major film studio. In New York they signed a contract with United Artists to make six films. An adaptation of Thunderball was to be their first production, but the legal problems with McCrory and others meant that instead they started work on a film version of $\mathrm{Dr} N o$, based on the novel that Fleming had 
adapted from his television outline. The film launched the cinema franchise, but it had its origins in television.

\section{Bond and The Man from U.N.C.L.E.}

Eon's putative Bond films were almost abandoned because of a dispute over television rights. In March 1961, Fleming had lunch in New York with the actress and film producer Ann Marlow (Lycett 1996: 388-9). She had produced some of the live television anthology series Somerset Maugham TV Theatre (CBS and NBC 1950-51) and the thriller writer and dramatist Maugham was himself a friend of Fleming's. Fleming was interested in Marlow both professionally and erotically, and at Sardi's restaurant he tore off part of the lunch menu and wrote a brief memo on the back of it naming Marlow as his representative for television and radio deals worldwide. This potentially obstructed the Eon deal for Bond adaptations because Eon wanted both exclusive film rights in perpetuity and also a holdback on television rights. A screen adaptation in one medium potentially undermines the profitability of an adaption in another, and producers normally require worldwide rights to all cinema adaptations before beginning a new production. Rights to showings of cinema films on television, and also filmed television programmes based on the same literary source, would normally be prohibited for a fixed period such as ten years. Moreover, Eon's contract gave the company an option to purchase rights for a Bond television series once the first three cinema films had been made. ${ }^{13}$ Charming but insistent correspondence with Marlow eventually resolved Fleming's problem, allowing Eon's $\operatorname{Dr}$ No film to reach the cinema screen. ${ }^{14}$ 
In 1962 the producer Norman Felton, whose Arena Productions company made television series for MGM for screening on the NBC network, was encouraged by the J. Walter Thompson advertising agency to meet Fleming in order to attach him to a putative secret agent television series (Walker 2011: 243). The agency was keen to find a drama that the Ford Motor Company might be keen to sponsor on NBC, and Fleming's name was expected to add value to the project, as had been the intention with the James Gunn project developed with Henry Morgenthau III (Lycett 1996: 420). Felton and Fleming spent three days together discussing ideas, including Fleming's suggestion that the central character would be American, and named Napoleon Solo (Walker 2011: 244). Negotiations with Felton got to the stage of specifying the degree of Fleming's involvement, if a US television network bought the series. ${ }^{15}$ Fleming offered to write story outlines for two episodes in each thirteen-episode production block, with a consultancy role that would give him input into the planning of each season (and thus presumably an on-screen credit as the creator of the series). To do this work, he asked for paid first-class air travel to Los Angeles and subsistence payments there for up to a month each year. Felton and Fleming exchanged ideas about details of the format including U.N.C.L.E.'s secret base, and Solo's interest in cooking, for example. However, Fleming was now seriously ill and was also aware that previous problems with Broccoli and Saltzman over competing television projects might undermine future cinema productions. Fleming therefore wrote to Felton, assigning all of his rights in the Napoleon Solo character to Felton for a token fee of one pound.

The series eventually appeared as The Man from U.N.C.L.E. with a distinctive blend of creative inputs from Felton and Fleming (Walker 2011: 251-3). But there was no 
explicit reference to Fleming or to Bond, after Eon's lawyers argued that such reference would damage the value of their new 1964 adaptation of Goldfinger (1959). The Man from U.N.C.L.E., having been substantially created by the British writer Fleming, and based on the British character of Bond, was sold back to Britain in the form of NBC's American television series with an American protagonist. It was broadcast by $\mathrm{BBC}$ in Britain, and related espionage adventure made and exported to the UK from the USA continued with I Spy (NBC 1965-8, ITV 1967-9) and Mission Impossible (Paramount for CBS 1966-73, ITV 1967-74), for example. As the 1960s wore on, the transatlantic nature of the spy television genre grew more marked, and it was less dependent on Britishness as an aspect of its formats.

The lack of a Bond television series is a structuring absence at the heart of the cycle of British, American and transatlantic spy adventure television series of the 1960s. Lew Grade's ITC production company sold the television series Danger Man to ITV in the UK and to the CBS network in the USA. The link to the spy drama genre was signaled explicitly by retitling the series Secret Agent for the American market. To capitalize on this success, ITC's The Saint began production in 1962, starring Roger Moore as a sophisticated international adventurer, based loosely on Leslie Charteris's novels but with a tone, characterisation and settings that closely resembled Bond and appealed to the American television market (Brown 1966). The Saint continued to be made until 1969, and ITC developed spy adventure series in hour-long colour film series for the rest of the decade and beyond. Some of ITC's adventure drama production featured an American protagonist based in a British setting, as in Man in a Suitcase (ITC for ITV 1967-8, ABC USA 1968), The Champions (ITC for ITV 1968-9, NBC 1968) and 
Strange Report (ITC for ITV 1969-70, NBC 1971), the latter of which was produced by Norman Felton, temporarily located in London himself.

British television channels had to limit their imports to less than 14 per cent of screen time, so the advantage of making programmes of this kind in the UK was that it satisfied the appetite for action-adventure formats made popular by imports but did not cut into the quota of imported programme time. Personnel and resources for making filmed television drama series in the UK became available because of the collapse of the 'B feature' industry of cinema production in the 1960s (Chibnall and McFarlane, 2009). Cinema personnel, studios and production methods were on hand, and staff from the USA and Canada were also coming to the UK, for reasons that included the continuing unease among creative workers following the witch-hunts of the House Un-American Activities Committee, and the start of the war in Vietnam (Neale 2005, Hilmes 2010). Historical series starting with The Adventures of Robin Hood in 1955 led to both ITV and $\mathrm{BBC}$ adopting 'American' forms and styles, then retaining distinctive 'Britishness' but framing it within spy adventure series in contemporary or futuristic settings. These programmes could be marketed to the US networks and other overseas markets. They addressed the concerns of young audiences, by means of representations of technological modernity, self-conscious play with inherited generic tropes and an awareness of the emergent pop counterculture. At the time, the genre had no name, though it is increasingly designated now as 'telefantasy' (Johnson 2005).

Filmed television series developed in Britain as a response to the import of filmed US television series in the 1950s, and spy adventure was recognized as a potential vehicle early on. For example, Howard Thomas, head of the commercial ITV company ABC that 
broadcast in London at weekends and all week in the Midlands, suggested a type of series based around Hollywood antecedents in the adapted thriller genre. His idea became The Avengers, created by ABC's head of drama, Sydney Newman:

as the percentage of realistic and gloomy plays increased I suggested to Sydney that our drama schedules need balancing with something more light-hearted and sophisticated.... Why couldn't we make a series based, for example, on The Thin Man, with characters like those made famous by William Powell and Myrna Loy? (Thomas 1977: 189)

Writing about The Avengers in the TV Times, the listings magazine for Britain's commercial channel, Kingsley Amis (1964) wrote that its protagonists were 'heroic freelancers who knock off a couple of world-wide conspiracies in the intervals of choosing their spring wardrobe. All of this is, so to speak, a wink at the audience, a joke shared with them'. Grade's company financed the making of action-adventure television series that were not adaptations of Bond properties as such, but they existed in the space for action, exoticism, sex and humour that Bond had carved out but had left vacant in television series drama.

One of the distinctive features of the British action-adventure series of the 1960s is their use of bold, colourful settings and costumes, which associates them with the selfconscious stylization and stylishness of the Bond films. The films' production design by Kenneth Adam, and elaborate title credit sequences, are indicative examples of the latter and the same aesthetic in television spy drama led to a report in the US entertainment industry newspaper Variety (Watkins 1965) that Secret Agent (aka Danger Man) had 'firmly nailed a once-predominant notion that British production values are too sluggish 
for the US "big-league" broadcasters'. The series was awarded 'Best Produced TV Program' of that year by the Screen Producers Guild. ITC made efforts to increase the production values of its action adventure series with the US market in mind, repudiating the gloomy and downbeat narratives that Americans had hitherto associated with British productions. ITC made the colour series The Baron (ITC for ITV 1966-7, ABC USA 1966), The Saint (in colour from 1966), The Avengers (in colour from 1966), and The Champions, for example, before domestic British audiences could see them in colour. The US networks were competing to increase the proportion of their colour programing in the mid-1960s, as a means to compete for the biggest share of the audience (Anon. 1965). The introduction of colour in British television occurred only from 1967 on BBC2, and ITC's main domestic market the ITV channel only converted to colour from 1969. Colour filming increased costs and problems of lighting for programme makers but was worth it for ITC's export chances, selling the spy series' visual appeal and fashionable, pop aesthetic. Colour brought television action adventure closer to the look of the cinema Bond, and to other British popular culture that could be assimilated into 'Cool Britannia' or Swinging London trends that had powerful international appeal (Miller 2000). In its annual report of 1966-67, the governing body for British commercial television, the Independent Television Authority (1967: 13), proudly asserted that the 'international' series must, in its attempt to be universally acceptable, lose some of the character of the series produced for the home audience alone; but series like The Avengers have shown that it is possible to achieve success overseas without losing the native savour. 
Just as $\mathrm{Dr} N o$ and its successors had done so successfully in the cinema, British filmed television spy series developed a format and aesthetic style that the commercial television channels had made both distinctively 'British' but also appealing to a large transatlantic audience.

The early history of Bond on screen is interesting in several ways as a study of remediation, intermediality and adaptation. The repeated failures to get a television Bond adaptation made are not unusual, but they demonstrate the significance of deal-making, and relationships between authors, agents and producers that are often overlooked. It was not in cinema that Bond first reached the screen, as is sometimes assumed, but as a live television play, a form whose history and cultural currency deserve further attention. Although the 1954 Casino Royale got lost and was quickly forgotten, it was just one example of the repeated moves to make Bond the hero of a television series in a fascinating period when live and filmed television drama and cinema were changing their relationships with each other and with other media. Because of the technical and industrial conditions affecting live studio drama, aesthetic and narrative features of the first screen Bond were wildly different from the films that came later. Some of Fleming's Bond writings derived from film and television screenplays, not the other way around, reversing the more usual novel-into-film teleology. Moreover, the success of the $\mathrm{Dr} N \mathrm{No}$ film and its sequels led to peaks in the sales of Bond novels after the release of each one. From Russia, with Love was announced as one of President Kennedy's ten favourite books in Life magazine (Sidey 1961), and it was in the USA that international Bondmania took hold most strongly. Bond novels were serialised in Playboy in 1963, 1964 and 1965. The most sustained period of paperback sales was from 1963 to 1967, when Sean 
Connery starred as Bond in Dr No, From Russia With Love, Goldfinger, Thunderball and You Only Live Twice (Lewis Gilbert 1967). A historiographic study of the medial transformations of Bond highlights that things might have been very different if a longrunning television Bond had been effectively realised. The massive popularity of the literary Bond, and the related success of Bond at the cinema which fed back into the sales of the books, made secret agent television series obvious prospects for others to exploit. While there was hardly a television Bond at all, he embodied the combination of sophistication, physical action and post-imperial globe-trotting that underlay the success of a whole cycle of television spy adventure in the 1960s that could never mention his name.

\section{Bibliography}

Amis, Kingsley, 'Looking-in is Looking Up!', TV Times, 9-15 February 1964, p. 7. Anon., 'Cinema. The New Pictures', Time, 29 October 1956. Anon., 'How “Casino Royale” (Climax!) was Recovered', Television Obscurities, 6 February 2009, http://www.tvobscurities.com/2009/02/climax-casino-royale/\#cite2 Anon., 'Trendex Color Study Grants NBC 77\% Advantage in Color Homes', Variety, 3 November 1965, p. 25.

Bennett, Tony and Janet Woollacott, Bond and Beyond: The Career of a Popular Hero (Basingstoke: Macmillan 1987).

Bignell, Jonathan, 'And the Rest is History: Lew Grade, Creation Narratives and Television Historiography', in Catherine Johnson and Rob Turnock (eds), ITV Cultures: 
Independent Television Over Fifty Years (Buckingham, Open University Press, 2005), pp. $57-70$.

--, 'Transatlantic Spaces: Production, Location and Style in 1960s-70s Action-adventure TV Series', Media History 16:1 (2010), 53-65.

Brown, Les, 'Britain Makes It on US TV - O'Seas Influence Makes its Mark', Variety, 30 June 1966, p. 1.

Chandler, Raymond, The Long Goodbye (Boston: Houghton Mifflin, 1953).

Chapman, James, Saints and Avengers: British Adventure Series of the 1960s (London: I.

B. Tauris, 2002).

Chibnall, Steve and Brian McFarlane, The British 'B' Film (London: British Film

Institute, 2009).

Fleming, Fergus (ed.), The Man with the Golden Typewriter: Ian Fleming's James Bond Letters (London and New York: Bloomsbury, 2015).

Fleming, Ian, Casino Royale (London: Jonathan Cape, 1953).

--, Live and Let Die (London: Jonathan Cape, 1954).

--, Moonraker (London: Jonathan Cape, 1955).

--, From Russia, with Love (London: Jonathan Cape, 1957).

--, Dr No (London: Jonathan Cape, 1958).

--, Goldfinger (London: Jonathan Cape, 1959).

-- For Your Eyes Only (London: Jonathan Cape, 1960).

--, Thunderball (London: Jonathan Cape, 1961).

Hawes, William, Filmed Television Drama, 1952-1958 (Jefferson: McFarland, 2002).

Hill, John, Sex, Class and Realism: British Cinema, 1956-1963 (London: BFI, 1986). 
Hilmes, Michele, "The "North Atlantic Triangle": Britain, the USA and Canada in 1950s Television', Media History, 16:1 (2010), 31-52.

Independent Television Authority, 'Drama Series and Serials', Annual Report and Accounts, 1966-67 (London: HMSO, 1967), p. 13.

Johnson, Catherine, Telefantasy (London: British Film Institute, 2005).

Kepley, Vance and William Boddy, 'From "Frontal Lobes" to the "Bob-and-Bob" Show:

NBC Management and Programming Strategies, 1949-65', in Tino Balio (ed.), Hollywood in the Age of Television (London: Unwin Hyman, 1980), pp. 41-89.

Koenig, Bill, ‘A Sampling of Ian Fleming’s U.N.C.L.E. correspondence’, The Spy Command (3 October 2015), https://hmssweblog.wordpress.com/2015/10/03/a-samplingof-ian-flemings-u-n-c-l-e-correspondence/

--, 'Text from Letters about Ian Fleming's U.N.C.L.E. Involvement', The Spy Command, undated, https://spycommandfeatures.wordpress.com/text-from-letters-about-ianflemings-u-n-c-1-e-involvement/ Lycett, Andrew, Ian Fleming (London: Phoenix, 1996).

Lyons, Kevin, ‘Dr No (1962) Production Notes', Encyclopedia of Fantastic Film and Television, 2009, http://www.eofftv.com/notes/d/dr_no_notes.htm.

Miller, Jeffrey, Something Completely Different: British Television and American Culture (Minneapolis, University of Minnesota Press, 2000).

Neale, Steven, 'Transatlantic Ventures and Robin Hood', in Catherine Johnson and Rob Turnock (eds), ITV Cultures: Independent Television Over Fifty Years (Buckingham, Open University Press, 2005), pp. 73-87.

Osborne, John, Look Back in Anger (London: Faber, 1957). 
Sidey, Hugh, ‘The President's Voracious Reading Habits’, Life, 17 March 1961.

Sillitoe, Alan, Saturday Night and Sunday Morning (London: W. H. Allen, 1958).

Thomas, Howard, With an Independent Air: Encounters During a Lifetime of

Broadcasting (London: Weidenfeld and Nicholson, 1977).

Walker, Cynthia, 'The Man from U.N.C.L.E.: Ian Fleming's Other Spy', in Robert G.

Werner et al. (eds), James Bond in World and Popular Culture: The Films are Not

Enough (Cambridge: Cambridge Scholars, 2011), pp. 239-56.

Watkins, Roger, 'British Prepare US Invasion - Majors, Indies Pitching New Shows', Variety, 3 November 1965, p. 25.

\footnotetext{
${ }^{1}$ Early versions of this chapter were presented as papers at the Association of Adaptation Studies conference, 'Adaptation and Multiplicities', Flagler College, FL in 2014, and at the 'TV Drama: The Forgotten, the Lost and the Neglected' conference, Royal Holloway University of London in 2015.

${ }^{2}$ A film copy of the 1954 CBS Casino Royale was discovered by accident in 1981, see Anon (2009). It is currently available on a DVD release of Climax! Mystery Theatre by TV Museum DVDs in the USA. Both complete and incomplete versions can also be seen on YouTube.

${ }^{3}$ The notion of the 'Bondian' to describe a complex interplay of narrative tropes, discursive tone and ideological currents is developed in detail in Bennett and Woollacott (1987).

${ }^{4}$ Letter from Fleming to his publisher Jonathan Cape, 6 October 1953, asking that all royalty cheques should be henceforth payable to Glidrose Ltd (F. Fleming 2015: 23). ${ }^{5}$ Letter from Fleming to Jonathan Cape, 18 September 1952, in F. Fleming (2015), pp. 17-19.

${ }^{6}$ Videotape was a cheaper medium for television production than film because tapes could be wiped and re-used, so many British videotaped dramas in the 1960-80 period became 'lost' unless film copies had been made for training purposes or overseas export. ${ }^{7}$ For a detailed discussion of US anthology drama series around 1954, including Climax! Mystery Theatre, see Hawes (2002), especially pp. 20-7.

${ }^{8} \mathrm{TV}$ studio cameras in the early 1950s did not have zoom lenses, but instead a rotating turret with three different lenses mounted on it. Smooth movements into or out of closeup (as opposed to cutting to another camera and back again, to conceal a change of lenses) were accomplished by physically moving the camera further from or nearer to the action, as occurs often in Casino Royale.
} 
9 The term 'film noir' was not in general use until the 1970s and producers of Climax! and other thriller series on American television described programmes as 'drama' or 'melodrama' (Hawes 2002).

${ }^{10}$ Kinescope is known as telerecording in the UK. Because the moving interlaced lines of an electronic image from broadcast television could not be captured as photographic frames by a film camera, film recording of broadcast pictures required a special television screen and a shutterless camera synchronized with it. This elaborate and expensive procedure was used mainly for 'transcribing' programmes so that they could be exported as reels of film for showing on incompatible, foreign television systems.

${ }^{11}$ Letter from Fleming to Michael Howard, 25 November 1955 (F. Fleming 2015: 98-9).

12 The lavish international settings of the film were a key aspect of the promotional discourses around it, e.g., see Anon. (1956).

${ }^{13}$ See letter from Fleming to Marlow, 15 October 1963, in F. Fleming (2015), pp. 260-1, and letter from Fleming to Sir William Stephenson, 16 August 1961, in F. Fleming (2015), pp. 288-90.

${ }^{14}$ See letters from Fleming to Marlow, 1 June 1961, 14 June 1961, 3 July 1961, 12 July 1961 and 15 August 1961, in F. Fleming (2015), pp. 249-55.

${ }^{15}$ See letter from the Ashley-Steiner agency to MGM (which held the television rights to Fleming's Bond material), 8 May 1963, reproduced in Koenig (2015), and letters from Felton to Fleming, 7 June 1963 and 8 July 1963, reproduced in Koenig (no date). 